\title{
How Nitric Oxide Down-Regulates Cryptochrome 1 from Canola in Blue but Not Red Light, and Reduces Hypocotyl Dwarfism in Lead and Drought Stress
}

\author{
Hossein Hamidi, Nahid Masoudian*, Mostafa Ebadi, Bostan Roudi, \\ Mohammad Hassan Khajehzadeh
}

Department of Biology, Damghan Branch, Islamic Azad University, Damghan, Iran

Received: 2 October 2018

Accepted: 17 February 2019

\begin{abstract}
Pollution of the environment and agricultural lands by lead and also drought stress is one of the important factors in reducing the production and quality of crops, including canola (Brassica napus L.). Expression of one key gene called cryptochrome 1 (CRY1) for reducing the hypocotyl dwarfism was analyzed in canola seedlings (Hyola 401 cultivar). We have studied the CRY1 gene on canola 5-day-old seedlings after exposure to sodium nitroprusside as the nitric oxide (NO) donor $(100 \mu \mathrm{M})$, lead $(100 \mu \mathrm{M})$, polyethylene glycol 6000 (PEG-6000) for imposed drought (5\%) and their combination $(100 \mu \mathrm{M}$ lead + PEG 5\%). The blue and red lights were irradiated for 2, 4 and 8 hours (h). A protocol for real-time quantitative PCR (RT-qPCR) analysis of this gene was developed using the $\beta$-actin gene as an internal standard. The CRY1 gene significantly up-regulated in drought and simultaneous lead and drought stresses in $8 \mathrm{~h}$ blue light irradiation. NO interaction considerably down-regulated the CRY1 gene in controlled seedlings and in all blue-light irradiations except for lead stress in $8 \mathrm{~h}$. This light in synchronous lead and drought stress led to significant hypocotyl dwarfism by CRY1, especially at $8 \mathrm{~h}$. Using NO interplay, hypocotyl dwarfism by CRY1 gene was reduced in all treatments except for red light and lead stress in 4 and $8 \mathrm{~h}$ of blue light.
\end{abstract}

Keywords: Cryptochrome 1, drought, dwarfism, lead, nitric oxide

\section{Introduction}

Abiotic stresses (for example, metals/metalloids, UV-B radiation, ozone, salinity, extreme temperatures,

*e-mail: nahidmasoudian@yahoo.com and drought) are among the most difficult dangers to agricultural systems and economic yields of crop plants [1]. Contamination of heavy metal in agricultural soils may cause the disorder of soil functionality and plant growth retardation, and affect human health by a contaminated food chain [2]. It was discovered that toxicity of lead decreases plant growth, nutrient uptake, and antioxidant enzyme activity by enhancing 
reactive oxygen species (ROS) contents in the shoots and roots of canola (Brassica napus L.) [3]. One of the inescapable outcomes of drought stress is an increase in ROS production in various cellular compartments, namely the chloroplasts and mitochondria [4]. The exposure to metals aggravates water stress in an added manner that causes plants to be more vulnerable to drought [5].

Light as a primary source of energy is one of the most important environmental factors for plant growth [6]. Plant photoreceptors connect light cues with physiologic responses, which determine how individual plants complete their lifestyles [7]. Cryptochromes (CRYs) of a plant are UV-A/blue-light photoreceptors that play essential roles in blue light-mediated responses by the regulated expression of more than 1,000 genes [8]. Recently, it has been reported that plant CRYs release ROS, including hydrogen peroxide $\left(\mathrm{H}_{2} \mathrm{O}_{2}\right)$ and superoxide $\left(\mathrm{O}_{2}^{-}\right)$subsequent to illumination [9-10]. Comparative proteomics analysis of the Cryptochrome 1 (CRY1) mutant and wild-type plants demonstrates that expression of several proteins associated with defense, stress, and detoxification are changed in the mutant plants [11-12], recommending a relationship between CRY1 function and plant resistance [13].

Nitric oxide (NO) acts as a cellular signaling molecule in plants [14]. Reduced ROS generation upon exogenous NO supplementation showed ROS scavenging activity of NO, and protection against lead toxicity [15]. Although enhanced drought tolerance via NO is related greatly to its ability to decrease stomatal opening and oxidative stress, it can very much influence other physiological processes, for example photosynthesis, proline accumulation and seed germination under the water deficit [16]. NO inhibits the opening of blue lightspecific but not opening of red light-induced [17].

Understanding the reducing dwarfism of hypocotyl encounter with lead stress, drought stress, and their combinations and knowledge about gene expression changes involved in it is important for canola improvement to spread in the world. Therefore, the objective of this study was to analyze the expression of the CRY1 gene in canola seedlings (Hyola 401 cultivar) under three different stress conditions using quantitative real-time PCR (qRT-PCR).

\section{Material and Methods}

\section{Plant Material and Growth Conditions}

Homogenous seeds of one cultivar of canola, namely Hyola 401, was acquired from Golestan University in Gorgan, Iran, and utilized in the analyses. The seeds were surface sterilized with a $2.5 \%(\mathrm{v} / \mathrm{v})$ sodium hypochlorite $(\mathrm{NaOCl})$ solution for 20 minutes (min), washed 5-8 times with distilled water to expel $\mathrm{NaOCl}$, and were then germinated and grown in petri dishes on two wet layers of filter paper in a controlled incubator at $25^{\circ} \mathrm{C}$ under conditions of $14 / 10$ hours day/night photoperiod.

After 5 days, lead levels (control and $100 \mu \mathrm{M}$ ) developed with lead(II) nitrate $\left[\mathrm{Pb}\left(\mathrm{NO}_{3}\right)_{2}\right]$, drought stress (control and 5\%) imposed by polyethylene glycol 6000 (PEG-6000) and NO levels as sodium nitroprusside (nitric oxide donor) (SNP) (control and 100 $\mu \mathrm{M}$ ) with three replicates were applied. Then controlled seedlings continued the same Light regime and other seedlings irradiated with blue (2, 4 and 8 hours) and red (2, 4 and 8 hours) light in the cabinets kept in the growth room at $25^{\circ} \mathrm{C}$. To maintain the constant desired nitric oxide concentration and moisture in petri dishes, the seedlings were sprayed with distilled water every hour. Gene expression and the hypocotyl length of seedlings were measured and averaged. All experiments were conducted in triplicate.

\section{Total RNA Extraction and cDNA Synthesis}

Extraction was performed using the total RNA isolation reagent (TRIR) (ABgene, United Kingdom). $50 \mathrm{mg}$ of samples (seedlings) were ground in liquid nitrogen and then dissolved in $0.8 \mathrm{ml}$ of the reagent buffer. After the addition of $0.2 \mathrm{ml}$ chloroform and centrifuging at $12000 \mathrm{~g}$ for $15 \mathrm{~min}$ at $4^{\circ} \mathrm{C}$ for phase separation, the aqueous phase containing RNA was ejected; an equivalent volume of isopropanol was added and after that centrifuged at $12000 \mathrm{~g}$ for $10 \mathrm{~min}$ at $4^{\circ} \mathrm{C}$. The supernatant was evacuated; the RNA pellet was washed doubly with $1 \mathrm{ml}$ of $75 \%$ ethanol and after that centrifuged at $7500 \mathrm{~g}$ for $5 \mathrm{~min}$ at $4^{\circ} \mathrm{C}$. The dry RNA pellet in diethyl pyrocarbonate (DEPC)-treated water was dissolved. The RNA concentration was estimated spectrophotometrically. Nearly $210 \mathrm{ng} / \mu \mathrm{l}$ of extracted RNA was afterwards applied to synthesize cDNAs using the QuantiTect Reverse Transcription Kit (Qiagen) in total reaction volume of $10 \mu \mathrm{l}$. To obtain $1 \mathrm{ml}$ of cDNA solution, sterilized distilled water was added to dilute the cDNA 500-fold.

Approximately $210 \mathrm{ng} / \mu 1$ RNA to prepare cDNA was mixed with gDNA wipeout buffer and then incubated at $42^{\circ} \mathrm{C}$ for $2 \mathrm{~min}$. Immediately, the reaction mix was chilled on ice for $2 \mathrm{~min}$. After that, the reverse transcriptase (RT) master mix and random hexamer oligo(dT) was added. Also, quantiscript reverse transcriptase was incubated at $42^{\circ} \mathrm{C}$ for $15 \mathrm{~min}$ and subsequently at $95^{\circ} \mathrm{C}$ for $3 \mathrm{~min}$.

\section{Real-Time Quantitative PCR (RT-qPCR)}

Sequences of canola CRY1 (accession no. AJ344565) were obtained from a gene bank (ncbi.nlm. nih.gov/BLAST/); then primers were designed using the Oligo 7 software. Real-time analysis was done utilizing IQ SYBR green super-mix (Bio-Rad) in an iCycler iQ detection system (Bio-Rad) under $95^{\circ} \mathrm{C}$ denaturation for $5 \mathrm{~min}$ one cycle followed by 50 cycles: $95^{\circ} \mathrm{C}$ for $90 \mathrm{~s}, 55^{\circ} \mathrm{C}$ for $30 \mathrm{~s}$, and $72^{\circ} \mathrm{C}$ for $45 \mathrm{~s}$. The 
CRY1 gene was detected using primers BnCRY1F (5'-GTGGAGAAAGGAACGAGGTTGTGGCACTG-3') and BnCRY1R (5'-CATGAGGCACTCTCGCAGATG TGGCAAC-3'). As internal control $\beta$-actin (accession No. AF111812) was utilized as an internal control using a forward primer (5'-GCTTCCCGATCAAGTCA-3') and reverse primer (5'-GGATTCCAGCTGCTTCCATTC-3'). Relative gene expression was calculated with the formula of fold induction 2-[ $[\Delta \mathrm{Ct}]$, where $\Delta \Delta \mathrm{Ct}=[\mathrm{Ct}$ GI (unknown sample) - Ct GC (unknown sample)] [Ct GI (reference sample) - Ct GC (reference sample)]. The Ct value shows the PCR cycle, at which the copy number passes the fixed threshold and can be at the beginning detected. GI is the gene of interest, and GC is the $\beta$-actin gene used as an internal control. The reference control was a sample showing expression of the gene of interest [18].

\section{Statistical Analysis}

The experiment was carried out in the randomized design with 3 replications. The statistical significance of the difference between parameters was evaluated by Duncan-test on SPSS software, and all graphs were drawn by excel software. The results are given in the text as $\mathrm{p}$, the probability values, and $\mathrm{p} \leq 0.05$ were adopted as the criterion of significance.

\section{Results}

\section{Quantitative Real-Time PCR Analysis of CRY1 Gene}

Expression of CRY1 gene in seedlings based on the dose and time courses of treatment was calculated quantitatively using $\mathrm{Ct}$ values. The high levels of

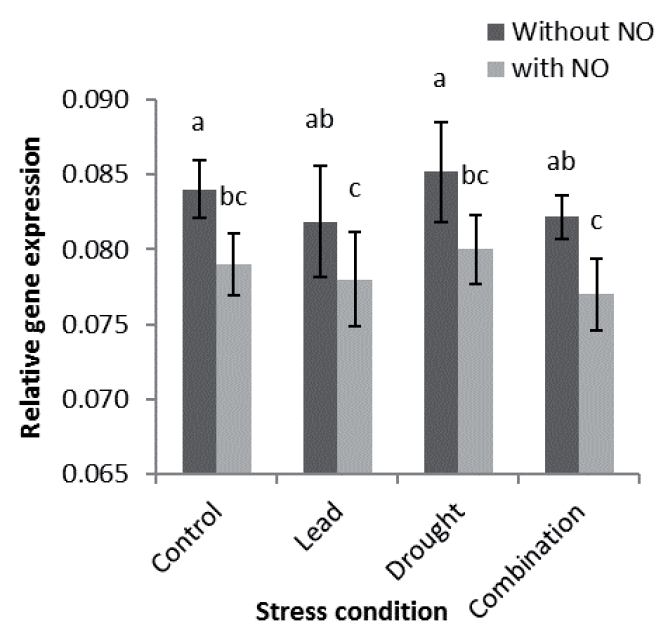

Fig. 1. Expression of the CRY1 gene relative to $\beta$-actin gene in canola (Brassica napus L.) seedlings treated with lead $(100 \mu \mathrm{M})$, PEG $(5 \%)$ and NO $(100 \mu \mathrm{M})$ in Controlled seedlings; common letters above columns indicate insignificant differences $(\mathrm{p} \leq 0.05)$ expression of CRY1 gene $(\mathrm{p} \leq 0.05)$ were observed at drought stress and simultaneous lead and drought in just 8 hours (h) of blue-light irradiation (Fig. 2c). As shown in all figures, a significantly changed expression in response to lead stress was not observed. Simultaneous
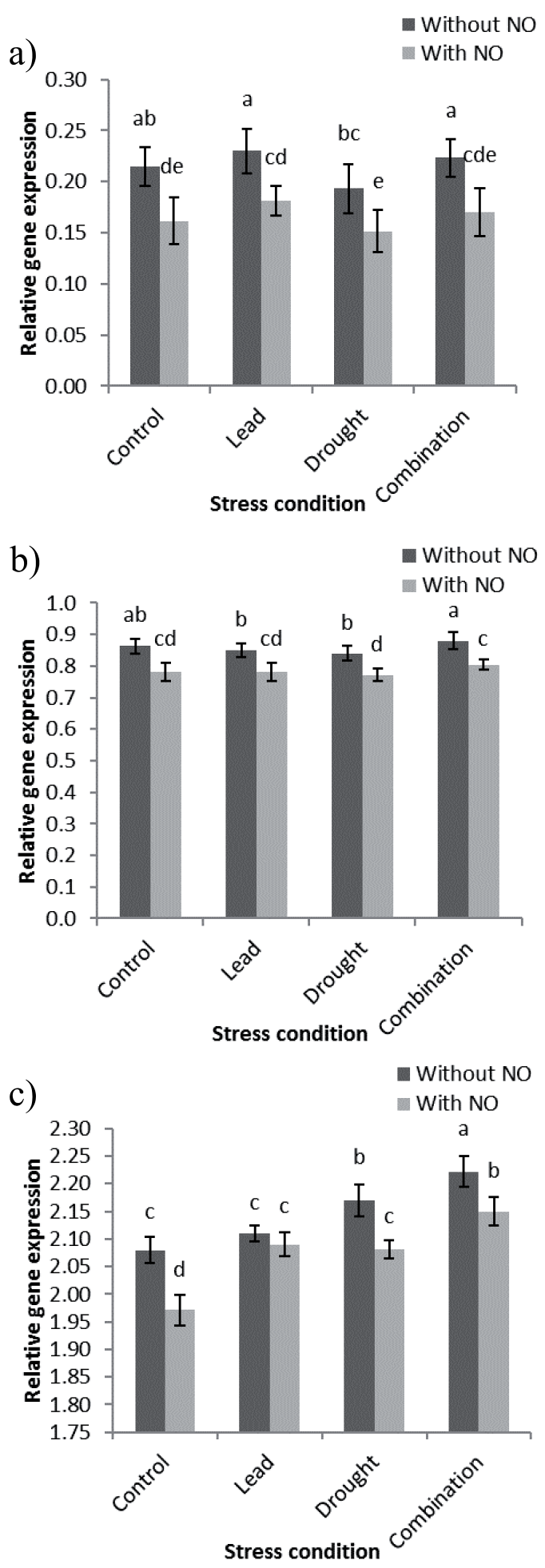

Fig. 2. Expression of the CRY1 gene relative to $\beta$-actin gene in canola (Brassica napus L.) seedlings treated with lead $(100 \mu \mathrm{M})$, PEG $(5 \%)$ and NO $(100 \mu \mathrm{M})$ with blue light for 2 a), 4 b) and 8 c) h; common letters above columns indicate insignificant differences $(\mathrm{p} \leq 0.05)$. 
lead and drought stress compared with lead, and drought stress considerably increased the expression of CRY1 gene in 4 and $8 \mathrm{~h}$ of blue-light irradiation (Figs 2b-c; $\mathrm{p} \leq 0.05)$. The combination lead and drought stress in $2 \mathrm{~h}$ of blue light (Fig. 2a) showed a significant increase compared to the drought stress, and did not significantly

a)

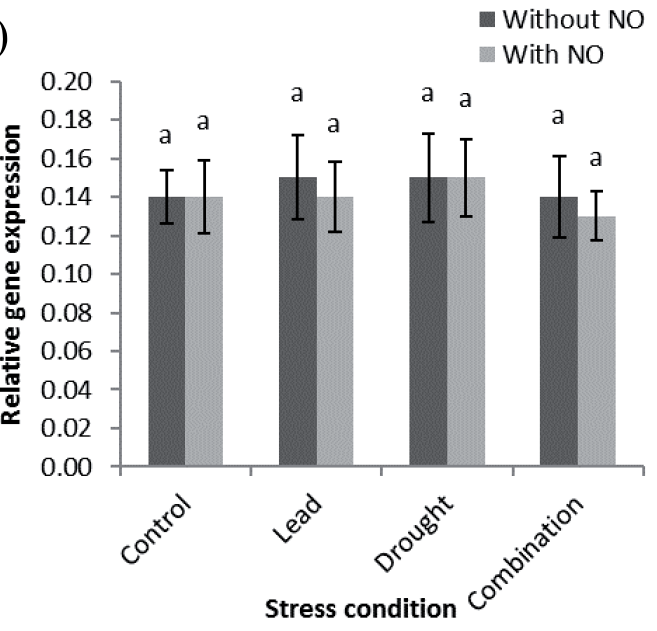

b)
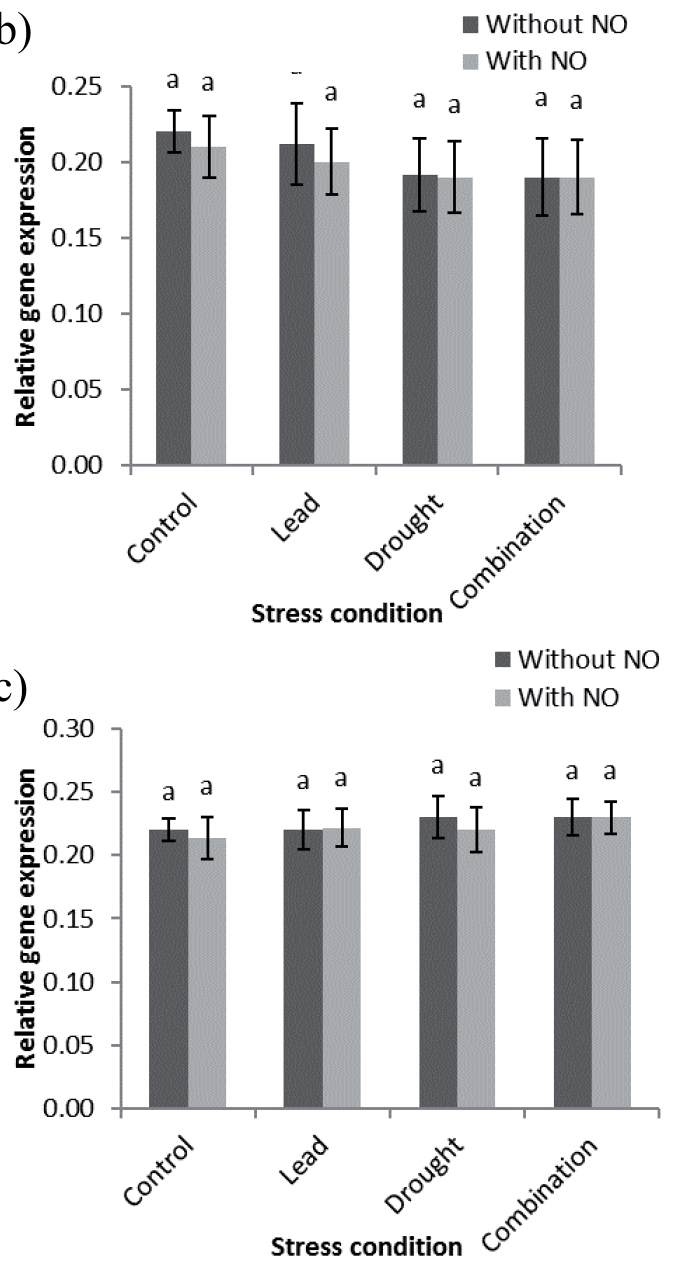

Fig. 3. Expression of the CRY1 gene relative to $\beta$-actin gene in canola (Brassica napus L.) seedlings treated with lead $(100 \mu \mathrm{M})$, PEG $(5 \%)$ and NO $(100 \mu \mathrm{M})$ with red light for $2 \mathrm{a}), 4 \mathrm{~b}$ ) and $8 \mathrm{c}$ ) h; common letters above columns indicate insignificant differences $(\mathrm{p} \leq 0.05)$. decrease compared to the lead stress. There was insignificant difference in controlled seedlings in all stresses (Fig. 1). No important difference was observed in all treatments during red-light exposure (Figs 3a-b-c).

Results showed that only in controlled seedlings (Fig. 1) and blue light within 2, 4 and 8, h (Figs 2a-b-c) elicitation, a reduction of CRY1 gene expression $(p \leq 0.05)$ at NO treatment in interaction with lights and stresses as compared to the control $(0 \mu \mathrm{M}$ SNP, $0 \mu \mathrm{M}$ lead and 0 PEG) was significant. There was insignificant reduction in all red lights (Figs 3a-b-c). With the application of $\mathrm{NO}$ and its interaction in CRY1 gene expression, except for lead stress in 8 hours of blue light (Fig. 2c) and all red-light treatments (Figs 3a-b-c), there was a significant decrease in lead, drought and synchronous lead and drought stresses. The results of NO interaction showed a considerable increase in the simultaneous lead and drought stress in the exposure to $8 \mathrm{~h}$ of blue light (Fig. 2c) compared to its effect on lead and drought and in $4 \mathrm{~h}$ of blue light (Fig. 2b) compared to drought, but there was no significant difference in other stresses. CRY1 gene expression in all red-light treatments did not significantly decrease or increase (Figs 3a-b-c).

\section{Avoided Dwarfism of Hypocotyl}

The seedlings were analysed in detail for decreases in dwarfism of hypocotyl. The seedlings in all stressed, except for drought in red and blue light for $8 \mathrm{~h}$, displayed significantly shorter hypocotyl $(\mathrm{p} \leq 0.05)$ when compared with control (Table 1). Hypocotyl dwarfism in simultaneous lead and drought stress, only in controlled seedlings and $2 \mathrm{~h}$ of red light importantly increased compared to lead stress. Comparison of hypocotyl dwarfism under synchronous lead and drought, stress conditions showed a significant decrease compared to drought.

We observed that the application of NO interplay in all treatments, except for lead stress in 4 and $8 \mathrm{~h}$ of blue light and all red-light treatments, led to a reduction in dwarfism (Table 1). The use of NO interaction in simultaneous lead and drought stress compared with lead stress significantly decreased dwarfism of the hypocotyl in $8 \mathrm{~h}$ of blue light, but significantly increased it in the controlled seedlings and $2 \mathrm{~h}$ of blue and $8 \mathrm{~h}$ of red light and increased or decreased insignificantly in other treatments. Hypocotyl dwarfism with the application of NO interplay in controlled seedlings, 2 and $4 \mathrm{~h}$ of light blue and $8 \mathrm{~h}$ of red light showed a significant increase in the simultaneous lead and drought stress compared with drought stress, but did not differ significantly in other stresses.

\section{Discussion}

Genome-wide analysis proposes the variable number of genes differentially expressed in the root 
Table 1. Effects of nitric oxide (NO) under lead, drought and simultaneous lead and drought stress on hypocotyl length of canola (Brassica napus L.) with unit centimeter $(\mathrm{cm})$.

\begin{tabular}{|c|c|c|c|c|c|c|c|c|}
\hline \multirow{3}{*}{$\begin{array}{c}\text { Stress } \\
(\mu \mathrm{M} * \%)\end{array}$} & \multirow{3}{*}{$\begin{array}{l}\text { Application of nitric } \\
\quad \text { oxide }(\mu \mathrm{M})\end{array}$} & \multirow{3}{*}{$\begin{array}{l}\text { Controlled } \\
\text { seedlings }\end{array}$} & \multicolumn{6}{|c|}{ Treatment time } \\
\hline & & & \multicolumn{2}{|c|}{$2 \mathrm{~h}$} & \multicolumn{2}{|c|}{$4 \mathrm{~h}$} & \multicolumn{2}{|c|}{$8 \mathrm{~h}$} \\
\hline & & & Blue & Red & Blue & Red & Blue & Red \\
\hline \multirow{2}{*}{$\begin{array}{l}\text { Control } \\
(0)\end{array}$} & Without nitrc oxide (0) & $4.5^{\mathrm{b} \pm} 0.09$ & $4.73^{b} \pm 0.08$ & $2.95^{\mathrm{a}} \pm 0.07$ & $2.31^{\mathrm{b}} \pm 0.06$ & $1.6^{\mathrm{a}} \pm 0.1$ & $1.4^{\mathrm{b}} \pm 0.06$ & $1.41^{\mathrm{ab}} \pm 0.08$ \\
\hline & With nitrc oxide (100) & $4.9^{\mathrm{a}} \pm 0.1$ & $5.1^{\mathrm{a}} \pm 0.11$ & $3.01^{\mathrm{a}} \pm 0.1$ & $2.71^{\mathrm{a}} \pm 0.1$ & $1.7^{\mathrm{a}} \pm 0.15$ & $1.6^{\mathrm{a}} \pm 0.07$ & $1.46^{\mathrm{a}} \pm 0.08$ \\
\hline \multirow{2}{*}{$\begin{array}{l}\text { Lead } \\
(100)\end{array}$} & Without nitrc oxide $(0)$ & $1.6^{\mathrm{e} \pm} 0.11$ & $1.41^{\mathrm{f}} \pm 0.08$ & $1.5^{\mathrm{bc}} \pm 0.12$ & $1.31^{\mathrm{ef}} \pm 0.12$ & $1.31^{\mathrm{bc}} \pm 0.09$ & $1.2^{\mathrm{cd}} \pm 0.1$ & $1.2^{\mathrm{cd}} \pm 0.07$ \\
\hline & With nitrc oxide (100) & $2.07^{\mathrm{d} \pm} 0.08$ & $1.9^{\mathrm{d}} \pm 0.13$ & $1.53^{\mathrm{bc}} \pm 0.19$ & $1.41^{\mathrm{de}} \pm 0.14$ & $1.28^{\mathrm{bc}} \pm 0.08$ & $1.26^{c} \pm 0.05$ & $1.3^{\mathrm{bc}} \pm 0.16$ \\
\hline \multirow{2}{*}{$\begin{array}{l}\text { Drought } \\
(5 \%)\end{array}$} & Without nitrc oxide $(0)$ & $2.1^{\mathrm{d}} \pm 0.05$ & $1.8^{\mathrm{d}} \pm 0.14$ & $1.61^{\mathrm{b}} \pm 0.09$ & $1.5^{\mathrm{d}} \pm 0.12$ & $1.41^{\mathrm{b}} \pm 0.12$ & $1.3^{\mathrm{bc}} \pm 0.08$ & $1.4^{\mathrm{ab}} \pm 0.13$ \\
\hline & With nitrc oxide (100) & $2.6^{\mathrm{c}} \pm 0.14$ & $2.3^{\mathrm{c}} \pm 0.16$ & $1.5^{\mathrm{bc}} \pm 0.09$ & $1.8^{\mathrm{c}} \pm 0.16$ & $1.4^{\mathrm{b}} \pm 0.16$ & $1.62^{\mathrm{a}} \pm 0.12$ & $1.5^{\mathrm{a}} \pm 0.05$ \\
\hline \multirow{2}{*}{$\begin{array}{c}\text { Combination } \\
(100 * 5 \%)\end{array}$} & Without nitrc oxide (0) & $1.3^{\mathrm{f}} \pm 0.11$ & $1.3^{\mathrm{f}} \pm 0.12$ & $1.3^{\mathrm{d}} \pm 0.11$ & $1.22^{\mathrm{f}} \pm 0.12$ & $1.2^{c} \pm 0.12$ & $1.1 \mathrm{~d} \pm 0.14$ & $1.11^{\mathrm{d}} \pm 0.09$ \\
\hline & With nitrc oxide (100) & $1.7^{\mathrm{e}} \pm 0.13$ & $1.6^{\mathrm{e}} \pm 0.08$ & $1.4^{\mathrm{cd}} \pm 0.18$ & $1.5^{\mathrm{d}} \pm 0.09$ & $1.3^{\mathrm{bc}} \pm 0.07$ & $1.62^{\mathrm{a}} \pm 0.11$ & $1.15^{\mathrm{d}} \pm 0.07$ \\
\hline
\end{tabular}

Values are mean $\pm \operatorname{SD}(\mathrm{n}=3)$. Common letters in a column indicate insignificant differences $(\mathrm{p} \leq 0.05)$.

in response to $\mathrm{Pb}, \mathrm{Cd}, \mathrm{Cr}(\mathrm{VI})$, and $\mathrm{As}(\mathrm{V})$ stresses [19]. Drought conditions can induce the expression of many genes related to planting stress, and their products are thought to act as cellular protectants against damage caused by stress [20]. In this research, we found the CRY1 gene to be significantly upregulated in response to drought and synchronous drought, and lead stresses in $8 \mathrm{~h}$ of blue-light irradiation (Fig. 2c). A recent observation that the crylcry2 double mutant showed an enhanced drought tolerance has led to a finding that CRYs also contribute to the blue-light stimulation of stomata opening [21]. In particular, Late embryogenesis abundant4-1 (LEA4-1) has been shown to play a prominent role in salt and drought tolerance in canola [22]; its abundance was relatively low (nearly four-fold) in Brassica juncea transgenics overexpressing CRY1 from Brassica napus (BnCRY1-OE) seedlings [23].

When NO interplay was applied to the seedlings, the CRY1 gene in Controlled seedlings and all blue-light treatments except for lead stress in $8 \mathrm{~h}$ did significantly down-regulate (Figs $1-2 ; \mathrm{p} \leq 0.05$ ). In response to high nitrogen $(\mathrm{HN})$ conditions, adenosine monophosphateactivated protein kinase (AMPK) mediating nuclear CRY1 phosphorylation triggers CRY1 degradation when total cellular CRY1 protein levels remain relatively stable, and after that inhibit oscillations of the circadian clock to interfere with floral control [24]. Similar to the HN condition, NO also causes the inhibition of flowered transition by repressing the CONSTANS and GIGANTEA circadian clock output genes [25].

CRY1 mediates primarily blue-light inhibition of hypocotyl elongation [26]. Here, we showed that $8 \mathrm{~h}$ of blue light in simultaneous lead and drought stress led to significant hypocotyl dwarfism via CRY1 (Table 1). It is suggested that CRYs activate anion channels, leading to plasma membrane depolarization and repression of cell elongation [27-30]. It is also proposed that a biological pathway linking root development/growth-related genes (CRY1 and CRY2) that has not been previously identified in different heavy metal stresses [19].

With the application of NO interaction, dwarfism of hypocotyl by CRY1 gene was reduced significantly in all stresses except for red light and lead in 4 and $8 \mathrm{~h}$ of blue light (Table 1). The NO due to the utilization of SNP is usefuli in that it provides enhanced germination, vigor and growth of seedlings [31]. Especially $100 \mu \mathrm{M}$ SNP has the best effect on promoting growth of the seedlings under lead toxicity [32]. Therefore, exogenous NO interplay can be utilized to alleviate lead toxicity [33]. Decreased NO levels prevent stomatal closure caused by SNP [34], so adding $\mathrm{NO}$ and its interaction can increase drought tolerance. Furthermore, [35] recently reported that the exogenous supply of NO enhances drought tolerance in sugarcane plants.

\section{Conclusions}

Finally, the results of real-time PCR showed that the use of NO interaction in lead, drought and simultaneous lead and drought stresses resulted in significant decreases in dwarfism of hypocotyl that were achieved due to changes in expression of the Cryl gene; therefore, inhibition of this key gene would promise to reduce dwarfism of hypocotyl. Future research may lead to elucidate more than the current study on responses observed by lead, drought and synchronous lead and drought stresses, such as the role of the CRY1 gene in reducing hypocotyl dwarfism.

\section{Acknowledgements}

Our thanks to Islamic Azad University of Damghan and the reviewers who helped to provide and publish this article. 


\section{Conflict of Interest}

There is no conflict of interest among the authors.

\section{References}

1. KHAN M.I.R., FATMA M., PER T.S., ANJUM N.A., KHAN N.A. Salicylic acid-induced abiotic stress tolerance and underlying mechanisms in plants. Front Plant Sci, 6, 462, 2015.

2. NWADINIGWE C.A., UDO G.J., NWADINIGWE A.O. Investigations of Heavy Metals Concentrations in Leaves of Telfairia occidentalis Hook. F. (Fluted Pumpkin) in Nigeria. Pol. J. Environ. Stud., 24 (4), 1733, 2015.

3. ALI B.M., MWAMBA T.M., GILL R.A., YANG C., ALI S., DAUD M.K., WU Y., ZHOU W. Improvement of element uptake and antioxidative defense in Brassica napus under lead stress by application of hydrogen sulfide. Plant Growth Regul, 74 (3), 261, 2014.

4. KAUR G., ASTHIR B. Molecular responses to drought stress in plants. Biol Plant, 61 (2), 201, 2017.

5. DE SILVA N.D.G., CHOLEWA E., RYSER P. Effects of combined drought and heavy metal stresses on xylem structure and hydraulic conductivity in red maple (Acer rubrum L.). J Exp Bot, 63 (16), 5957, 2012.

6. DONG C., FU Y., LIU G., LIU H. Low light intensity effects on the growth, photosynthetic characteristics, antioxidant capacity, yield and quality of wheat (Triticum aestivum L.) at different growth stages in BLSS. Adv Space Res, 53 (11), 1557, 2014.

7. LI F.W., MATHEWS S. Evolutionary aspects of plant photoreceptors. J Plant Res, 129 (2), 115, 2016

8. YANG Z., LIU B., SU J., LIAO J., LIN C., OKA Y. Cryptochromes orchestrate transcription regulation of diverse blue light responses in plants. Photochem Photobiol, 93 (1), 112, 2017.

9. CONSENTINO L., LAMBERT S.1., MARTINO C., JOURDAN N., BOUCHET P.E., WITCZAK J., CASTELLO P., EL-ESAWI M., CORBINEAU F., D'HARLINGUE A., AHMAD M. Blue-light dependent reactive oxygen species formation by Arabidopsis cryptochrome may define a novel evolutionarily conserved signaling mechanism. New Phytol, 206 (4),1450, 2015.

10. JOURDAN N., MARTINO C.F., EL-ESAWI M., WITCZAK J., BOUCHET P., D'HARLINGUE A., AHMAD M. Blue-light dependent ROS formation by Arabidopsis Cryptochrome-2 may contribute towards its signaling role. Plant Signal Behav, 10 (8), e1042647, 2015.

11. PHEE B.K., PARK S., CHO J.H., JEON J.S., BHOO S.H., HAHN T.R. Comparative proteomic analysis of blue light signaling components in the Arabidopsis cryptochrome 1 mutant. Mol Cells, 23 (2), 154, 2007.

12. YANG Y., LI Y., LI X., GUO X., XIAO X., TANG D., LIU $\mathrm{X}$. Comparative proteomics analysis of light responses in cryptochrome1-304 and Columbia wild-type 4 of Arabidopsis thaliana. Acta Biochim Biophys Sinica, 40 (1), 27, 2008

13. WU L., YANG H.Q. CRYPTOCHROME 1 is implicated in promoting $\mathrm{R}$ protein-mediated plant resistance to Pseudomonas syringae in Arabidopsis. Mol Plant, 3 (3), 539, 2010.

14. BESSON-BARD A., GRAVOT A., RICHAUD P., AUROY P., DUC C., GAYMARD F., TACONNAT
L., RENOU J., PUGIN A., WENDEHENNE D. Nitric oxide contributes to cadmium toxicity in Arabidopsis by promoting cadmium accumulation in roots and by up-regulating genes related to iron uptake. Plant Physiol, 149 (3),1302, 2009.

15. KAUR G., SINGH H.P., BATISH D.R., MAHAJAN P., KOHLI R.K., RISHI V. Exogenous nitric oxide (NO) interferes with lead $(\mathrm{Pb})$-induced toxicity by detoxifying reactive oxygen species in hydroponically grown wheat (Triticum aestivum) roots. PLoS One, 10 (9), e 0138713, 2015.

16. SANTISREE P., BHATNAGAR-MATHUR P., SHARMA K.K. NO to drought-multifunctional role of nitric oxide in plant drought: do we have all the answers? Plant Sci, 239, 44, 2015.

17. ZHANG X., TAKEMIYA A., KINOSHITA T., SHIMAZAKI K. Nitric oxide inhibits blue light-specific stomatal opening via abscisic acid signaling pathways in Vicia guard cells. Plant Cell Physiol, 48 (5), 715, 2007.

18. PFAFFL M.W. A New Mathematical Model for Relative Quantification in Real-Time RT-PCR, Nucleic Acids Res, 29 (9), e45, 2001.

19. DUBEY S., SHRI M., MISRA P., LAKHWANI D., BAG S.K., ASIF M.H., TRIVEDI P.K., TRIPATHI R.D., CHAKRABARTY D. Heavy metals induce oxidative stress and genome-wide modulation in transcriptome of rice root. Funct Integr Genomics, 14 (2), 401, 2014.

20. YAMAGUCHI-SHINOZAKI K., SHINOZAKI K. Transcriptional regulatory networks in cellular responses and tolerance to dehydration and cold stresses. Annu Rev Plant Biol, 57, 781, 2006.

21. MAO J., ZHANG Y.C., SANG Y., LI Q.H., YANG H.Q. A role for Arabidopsis cryptochromes and COP1 in the regulation of stomatal opening. Proc Natl Acad Sci USA, 102 (34), 12270, 2005.

22. DALAL M., TAYAL D., CHINNUSAMY V., BANSAL K.C. Abiotic stress and ABA-inducible Group 4 LEA from Brassica napus plays a key role in salt and drought tolerance. J Biotechnol, 139 (2), 137, 2009.

23. SHARMA P., CHATTERJEE M., BURMAN N., KHURANA J.P. Cryptochrome 1 regulates growth and development in Brassica through alteration in the expression of genes involved in light, phytohormone and stress signalling. Plant Cell Environ, 37 (4), 961, 2014.

24. YUAN S., ZHANG Z.W., ZHENG C., ZHAO Z.Y., WANG Y., FENG L.Y., NIU G., WANG C.Q., WANG J.H., FENG H., XU F., BAO F., HU Y., CAO Y., MA L., WANG H., KONG D.D., XIAO W., LIN H.H., HE Y. Arabidopsis cryptochrome 1 functions in nitrogen regulation of flowering. Proc Nat Acad Sci USA, 113 (27), 7661, 2016.

25. HE Y., TANG R.H., HAO Y., STEVENS R.D., COOK C.W., AHN S.M., JING L., YANG Z., CHEN L., GUO F., FIORANI F., JACKSON R.B., CRAWFORD N.M., PEI Z.M. Nitric oxide represses the Arabidopsis floral transition. Science, 305 (5692), 1968, 2004.

26. MA D., LI X., GUO Y., CHU J., FANG S., YAN C., NOEL J.P., LIU H. Cryptochrome 1 interacts with PIF4 to regulate high temperature-mediated hypocotyl elongation in response to blue light. Proc Natl Acad Sci USA, 113 (1), 224, 2016.

27. CHO M.H., SPALDING E.P. An anion channel in Arabidopsis hypocotyls activated by blue light. Proc Natl Acad Sci USA, 93 (15), 8134, 1996. 
28. PARKS B.M., CHO M.H., SPALDING E.P. Two genetically separable phases of growth inhibition induced by blue light in Arabidopsis seedlings. Plant Physiol, 118 (2), 609, 1998

29. SPALDING E.P. Ion channels and the transduction of light signals. Plant Cell Environ, 23 (7), 665, 2000.

30. SPALDING E.P., COSGROVE D. Large plasma-membrane depolarization precedes rapid blue-light-induced growth inhibition in cucumber. Planta, 178 (3), 407, 1988

31. PIRES R.M.O., SOUZA G.A., CARDOSO, A.A., DIAS D.C.F.S., BORGES E.E.L. Action of nitric oxide in sesame seeds (Sesamum indicum L.) submitted to stress by cadmium. J Seed Sci, 38 (1), 22, 2016.

32. BAI X.Y., DONG Y.J., WANG Q.H., XU L.L., KONG J., LIU S. Effects of lead and nitric oxide on photosynthesis, antioxidative ability, and mineral element content of perennial ryegrass. Biol Plant, 59 (1),163, 2015.

33. SADEGHIPOUR O. Pretreatment with nitric oxide reduces lead toxicity in cowpea (Vigna unguiculata L. Walp.). Arch Biol Sci, 68 (1), 165, 2016.

34. SHE X.P., SONG X.G. Ethylene inhibits abscisic acidinduced stomatal closure in Vicia faba via reducing nitric oxide levels in guard cells. NZJ Bot, 50 (2), 203, 2012.

35. SILVEIRA N.M., HANCOCK J.T., FRUNGILLO L., SIASOU E., MARCOS F.C.C., SALGADO I., MACHADO E.C., RIBEIRO R.V. Evidence towards the involvement of nitric oxide in drought tolerance of sugarcane. Plant Physiol Biochem, 115, 354, 2017. 